\title{
$5 \quad$ Innovating social housing? Tracing the social in social housing construction
}

\author{
Michael Friesenecker and \\ Katharina Litschauer
}

\section{Introduction}

Since the 1980s, the traditional role of social housing in Europe which aimed to ensure affordable housing for a broad cross-section of its citizens - has become increasingly threatened by public expenditure pressures, liberalisation and privatisation (Scanlon et al., 2015). The changing economic and political context has forced many countries and cities to adapt their social housing approaches. Some cities and countries have privatised (parts of) their social housing to sitting tenants, such as the UK's Right to Buy programme (ibid); retreated from active housing policies and public financial support, like Berlin (Marquardt and Glaser, 2020); or transformed public social housing into market-based cooperatives, like Stockholm (Andersson and Turner, 2014). Meanwhile, Austria and France actually expanded their social housing sector, but the sector became increasingly fragmented, though the term social in social housing remains meaningful (Lévy-Vroelant et al., 2014). Following this diverse landscape, Granath Hansson and Lund (2019, p. 149) claim that, across Europe, social housing has increasingly become a 'floating signifier' without an agreed meaning, though a focus on households with limited financial resources is observable. However, social housing in Vienna contrasts with this narrow definition, as it aims to cater for broad sections of the population and consists of both affordable and high-quality housing.

Against this background, this chapter analyses how social housing construction in Vienna has been adapted in light of a changing urban context and explores how the social in social housing has been redefined since 1990. In doing so, we draw on the concept of 'social innovation', which refers to innovation as the capacity to create and implement new solutions that meet the social needs of social groups or the challenges of society as a whole (BEPA, 2010). Changing housing 
needs due to labour market restructuring, immigration, climate and societal change present such challenges (Braga and Palvarini, 2013). This raises the question of how Vienna deals with these challenges and how this in turn re-shapes social housing. Social innovation, as our analytical focus, allows us to explore how social housing is more than the provision of affordable housing for low-income households. It highlights how the social in housing is contested and re-negotiated, rooted in the relations and behaviour of multiple actors across multiple levels. Following Reinprecht (2021), we investigate shifts in the regulatory framework and highlight changes in both the actors' constellations and the prevailing system of norms and values.

Although Vienna retreated from state provision by handing the task of social housing construction to limited-profit housing associations (LPHAs), the City continues to steer new construction by drawing on a specific set of policy instruments and actors. The concept of 'statedirected hybridity' (Mullins et al., 2017) emphasises the decisive role of the state in shaping social agendas of (limited-profit) housing associations and allows for an analysis of the extent to which the City retained its power to actively influence the social. As such, we can grasp how policy instruments have reshaped both values and actors' constellations within social innovation.

To evaluate the outcome of social innovation, we draw on Fainstein's (2010) concept of a 'just city' - according to which the status of a just city should be analysed against the core values of equity, diversity and democracy. Each of these three criteria must be present at a minimum level, even though they are in tension with one another and can never all be fully realised. Diversity allows for an analysis of how the City recognises changing and diverse housing needs. Regarding democracy, we investigate the involvement and participation of different actors, in particular, the empowerment of residents to become co-producers rather than mere consumers of their living environment (Moulaert, 2010). Equity focuses on redistributive outcomes and highlights aspects of eligibility, access and affordability. This analytical framework allows us to shed light on how social innovations redefine the social in just ways as we assess how trade-offs between equity, diversity and democracy influence the constant re-negotiation of the social.

\section{The city's steering role in social housing construction}

Social housing has a long tradition in Vienna and is provided by both the municipality and LPHAs. Even from its roots in the era of Red 
Vienna (1922-1934), Vienna's municipal housing construction aimed to address the housing needs of the time, which were marked by poor housing conditions and the common practise of subletting single beds within the private rental market. Municipal housing provided apartments with lavatories and running water, as well as communal infrastructure, such as schools, libraries, green spaces and common washing and laundry rooms. The aim of providing these central elements was to enhance the living standards of the working class and municipal servants (Lévy-Vroelant and Reinprecht, 2014; Kadi and Suitner, 2019). In a similar vein, the origins of LPHAs lie in the collective, self-managed housing provision of cooperatives, especially after the First World War, as well as employer initiatives to provide decent housing for their staff (Bauer, 2006). After the Second World War, Vienna's focus shifted towards the mass production of housing throughout the 1950s, and improvements in apartment quality throughout the 1960s. These efforts were supported by the introduction of housing subsidies on a national level and the reinstatement of the non-profit housing law. The latter became crucial cornerstones of Austria's postwar housing policy and paved the way for LPHAs (Matznetter, 2002). The 1970s saw the return to greater architectural diversity, higher construction quality and a renewed interest in experimenting with collaborative housing and communal infrastructure. However, this development mainly took place in the limited-profit sector (Schluder, 2005).

After the fall of the Iron Curtain in 1989 and Austria's accession to the European Union, Vienna faced particularly profound political and socio-demographic challenges that also affected social housing provision. After decades of stagnation, population growth increased the demand for housing and brought new challenges in an ever more densely populated city. Without abandoning its core value of providing social housing for many, social-democratic Vienna was forced to adapt its social housing provision as a reaction to new EU budgetary and state aid regulations. Figure 5.1 shows how the construction of social housing by LPHAs already outweighed municipal housing construction throughout the 1990s, whilst the latter ceased completely in 2004 (see Chapter 4 by Litschauer and Friesenecker in this volume). LPHAs became even more important in constructing outsourced public housing as public-private partnerships. Against this context, social housing construction became increasingly characterised as a statedirected hybridity in which the political-administrative apparatus defines its goals, whilst organisational-economic implementation was handed over to the housing associations (Bauer, 2006, p. 24). 


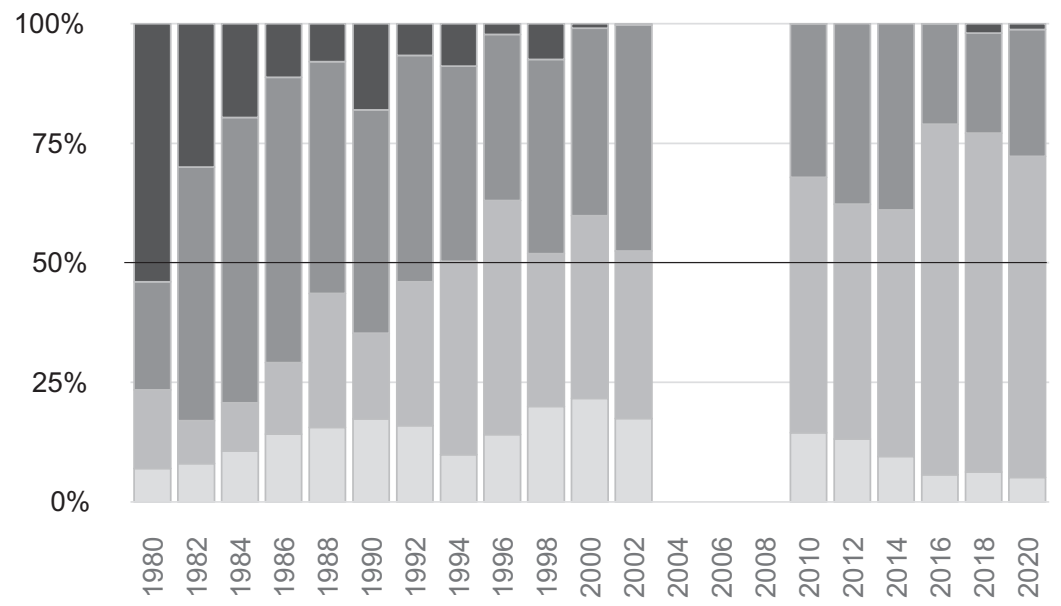

$\square$ Natural Person $\square$ Legal Person $\quad$ LPHA $^{*} \quad \square \quad$ Municipal Housing

Figure 5.1 Share of building permits for dwellings per developer in Vienna (\%), 1980-2020.

Source: STATcube - Statistische Datenbank von STATISTIK AUSTRIA Baumaßnahmenstatistik; Author's own elaboration.

Note: *Limited-profit housing associations. For 1980-2002 building permits for apartments in new buildings plus attics conversions and extensions. For 2003-2009 no data available. For 2010-2020 building permits for dwellings in new buildings only. Figures for 2017-2020 are estimated.

LPHAs are one of the core actors in today's social housing construction and have been regulated by the national Limited-Profit Housing Act since 1978. LPHAs can either be organised as cooperatives, owned by its members or as limited liability corporations. Legally, the distribution of profits is limited to $3.5 \%$, which is why they do not aim at maximising profits. Furthermore, housing associations are obliged to reinvest profits into housing, but in exchange they benefit from tax exemptions. Hence, the core values of these third sector actors are the provision of affordable housing through cost-covering rent and inter-generational housing provision through long-term maintenance and reinvestment into housing (GBV, 2021).

Figure 5.1 highlights the importance of LPHAs in housing construction in relation to commercial developers. Whilst commercial developers were only marginally active until the late 1980s, they became a strong competitor for LPHAs as the municipality progressively retreated from construction. Nevertheless, the City continues to manage 


\section{Distribution and Size of Social Housing Premises, Vienna}

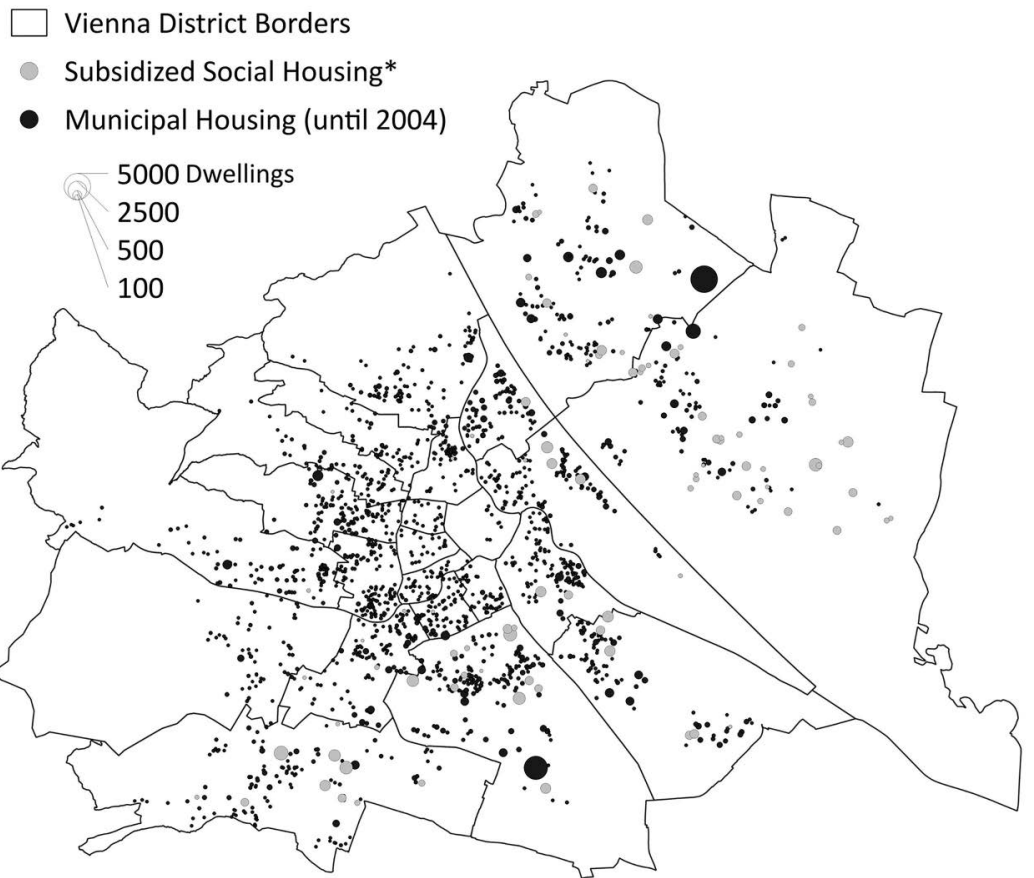

Figure 5.2 Distribution of municipal housing stock and new subsidised housing construction via developer competitions, 2020.

Sources: CC BY 3.0 data.gv.at for municipal housing. For subsidised social housing: Descriptions of developer competitions, Wohnfonds Wien - https://bit.ly/3esbvMQ, Author's own elaboration.

Note: *Output of developer competitions since 1995 and built until 2020; mainly constructed by limited-profit housing associations (LPHA).

its existing municipal housing stock. Figure 5.2 shows that municipal housing and, as far as possible, new subsidised social housing are distributed across the whole city. This is emblematic of Vienna's core values in housing policy: to avoid segregation across the city and provide mixed social housing to a broad section of the population.

As the historical trajectory of social housing provision in Vienna highlights, the core values of the municipality and the LPHAs shape the social in social housing. Nevertheless, in retreating from the construction of municipal housing, the City had to find new ways to secure its core values in social housing construction and sustain limited-profit 
housing. Albeit in a steering role, the City's approach to influencing the social in social housing construction has built on three highly interrelated policy instruments: (1) through an active land banking and zoning policy that guarantees affordable building plots; (2) by subsidising housing construction to ensure low housing costs; and (3) through steering the criteria included in developer competitions to ensure the social orientation and housing quality. We elaborate on each of these below.

The introduction of a City-owned land provision fund in 1985 today known as the wohnfonds_wien (Housing Fund of Vienna) - laid the groundwork for Vienna's active land banking policy. As the Executive Councillor for Housing is the president of the fund, the core values of the City's housing policy are clearly reflected in the fund's strategic orientation and objectives. The main objective is central land acquisition to keep land prices low, limit competition between (limited profit) developers and secure land for future urban developments. For the construction of subsidised social housing in recent decades, the fund started to buy land in planned urban development areas from the late 1980s onwards (Schluder, 2005, p. 15). The provision of affordable land is key to (subsidised) social housing as the overall land costs are capped to ensure below-market rents. Nevertheless, from 2008 onwards, the City faced severe challenges in buying up land because commercial developers became a strong competitor and land prices increased (see Figure 5.1). As a consequence, Vienna increased its commitment to an active land banking and zoning policy and introduced a new social housing zoning category in 2018. This applies to large, newly rezoned building plots and demands that at least half of all housing units must be subsidised social housing. For these units, rent caps and a ban on resale apply for the duration of the subsidy (usually 40 years).

While various European countries, such as the Czech Republic, England and Sweden (Scanlon et al., 2015), have shifted their housing subsidies to individual housing allowances at the expense of their social housing supply, Vienna continues to subsidise housing construction. In 2017, for instance, around 50\% of expenses were used for new construction, $34 \%$ for subsidised renovation and around $16 \%$ for housing allowances (Mundt et al., 2018). With the devolution of the centralised Austrian housing subsidy system to the regional level, Vienna - which is both a Bundesland and a municipality - became legally responsible for housing subsidies in 1989. The subsidies are mainly financed through a $1 \%$ housing tax on wages, which is equally paid by employers and employees, collected at the national level and distributed to the Bundesländer (Marquardt and Glaser, 2020). The 
decentralisation of housing subsidies granted the City of Vienna the legal autonomy to develop subsidy schemes, define target groups and income limits, allocate part of the housing units, and regulate rent for the duration of the subsidy (35-40 years). Hence, housing subsidies allow the City to influence not only affordability (by providing cheap financing and implementing a rent cap), but also to demand certain housing qualities as specified in the subsidy schemes.

In contrast to other European countries, except for Scandinavian welfare regimes (Lévy-Vroelant et al., 2014, p. 285), Austria - but especially Vienna - mainly subsidises the construction of multi-storey rental unit housing. Vienna's bricks-and-mortar subsidies consist largely of loans, which generate a stable stream of revenue for financing future housing construction. Additionally, non-repayable grants contribute to fostering (ecological) housing qualities. In practice, housing subsidies are mostly dispersed to LPHAs, while commercial developers also rarely construct subsidised (social) housing. It is important to note that rent regulations apply for the duration of the subsidy loan; hence private subsidised housing can only temporarily be considered social housing. In contrast, LPHAs are only allowed to charge cost-covering rent, implying that the rent must be lowered substantially after subsidy loans are paid back (Marquardt and Glaser, 2020). Hence, LPHAs are legally obliged to construct permanent social housing. Furthermore, profits must be re-invested in renovation or new constructions, thereby providing affordable, high-quality housing and securing social housing in the long run.

Moreover, the major tool that allows the City to shape the social orientation of subsidised housing is its developer competitions, organised by the wohnfonds_wien. Introduced in 1995 as an architectural and urban design competitive tender procedure, it is the main tool to allocate City-owned building plots and housing subsidies. These apply to large development projects (more than 500 units since 2016) on City-owned land and/or projects that receive housing subsidies. Smaller projects are evaluated by a property advisory board. As well as LPHAs, commercial developers are also allowed to take part in these competitions. While the city administration disburses the subsidy, the tendering process is implemented by the wohnfonds_wien. Competitions demand that developers team up with architects, landscape architects and other experts, and competition calls often include specific themes. Through a multi-disciplinary jury, consisting of experts in architecture, urban design, ecology, etc., as well as representatives of the districts, the city administration and wohnfonds_wien award the best projects. The assessment follows economic, architectural, ecological 
criteria and, since 2009, the criterion of social sustainability. These criteria are politically determined which explains why they go beyond pure economic aspects. Furthermore, as outlined above, rent in newly constructed, subsidised social housing is capped. Therefore, projects must fulfil the requirement of providing affordable housing, while the competitive tendering procedure demands innovative, high-quality housing solutions. In this sense, developer competitions are understood by the administration as a steering instrument that ensures high-quality housing and fosters social innovation.

\section{Innovating social housing construction via developer competitions in just ways?}

After outlining how Vienna continues to shape social housing construction by drawing on different policy instruments, this section analyses how the social in social housing has been adapted and innovated through developer competitions. We trace how these social innovations were articulated in response to urban challenges and analyse them with regard to trade-offs between equity, diversity and democracy. First, we discuss how housing needs have been recognised in developer competitions and how this has influenced housing outcomes with regard to diversity and equity. Second, we analyse how the tendering procedure has been innovated, incorporating participatory elements for residents, and how this has improved democracy.

\section{Innovating high-quality, yet affordable social housing}

After being introduced in 1995, developer competitions were based on specific themes and used by the administration as the main tool to influence the orientation of new social housing construction. In his evaluation of developer competitions, Liske (2008) concludes that, until 2008, more than half of the competitions had been theme-oriented, focusing on ecological and social aspects. As Vienna committed itself to climate mitigation policies during the 1990s, ecological issues were also taken up in developer competition calls. While passive housing standards and wood construction remained experimental, low-energy buildings, ecological building site management and ventilation systems for reducing the heating demands became general standards in (social) housing construction. This mainstreaming of high ecological standards became possible because the criteria of architecture, economy and ecology were treated as equally important in the evaluation procedure (Schluder, 2005; Liske, 2008). 
At the beginning of the 21st century, socio-demographic changes and migration became more pronounced. The City of Vienna increasingly recognised the housing needs of disadvantaged groups in urban planning, including women, migrants, young and elderly people, as well as disabled persons (MA18, 2005). Subsequently, topics of intercultural, inter-generational and female-orientated living, or housing solutions for single adults and affordable housing for younger generations were taken up as special themes in the competition calls (Reven-Holzmann, 2019). These themed tenders led to the provision of diverse apartment layouts, ranging mostly in size and the numbers of rooms, accommodating different housing needs. This is a development that should not be underestimated as, in the 1990s, usually only one type of ground floor plan for the nuclear family had been foreseen (Schluder, 2005).

Following these experiences, the design of the tendering procedure was modified in 2009 to explicitly integrate the housing needs of different social groups, while adding social sustainability as a fourth evaluation criterion. This criterion emphasises the usability of apartments, buildings and (semi-)public spaces in everyday life, but also fostering collaborative living and serving diverse housing needs. Developer competitions initially encouraged the provision of private free space in the form of gardens, loggias and balconies, and from 2009 onwards barrier-free designs became standard (Reven-Holzmann, 2019). Most importantly, following the legacy of the Red Vienna era, the provision of communal spaces was (re)emphasised along with the introduction of social sustainability. Communal spaces vary from project to project, including fitness rooms, swimming pools or multipurpose rooms for birthday celebrations or family gatherings, but the most requested communal spaces are still laundry rooms (Reven-Holzmann, 2019). Often not realised due to budget restrictions in projects of the 1990s and 2000s (Schluder, 2005), recent competitions have highlighted the importance and accessibility of green and open spaces for different user groups and ages, including semi-public spaces, like rooftops. Therefore, special emphasis is placed on the qualities of playgrounds and parks, including urban gardening infrastructure, which gained momentum in recent years.

However, some local experts began to address an increasing tradeoff between improved housing quality and affordability. Especially after the mid-2000s, in the context of renewed population growth and price increases in the construction sector, improved building standards led to higher costs for tenants, especially regarding capital contributions (Liske, 2008). The global financial crisis of 2008 further aggravated the situation as real estate became attractive for commercial 
developers and affordable building plots scarce for LPHAs. In light of these developments, affordability became the dominant theme and calls for tender progressively emphasised housing costs.

A tendering competition in 2012 saw a first experimental attempt to cap construction costs, down-payments and rent levels, by limiting floor size (Reven-Holzmann, 2019). Following its success, this experiment was further mainstreamed to the SMART Housing Program (Wohnfonds Wien, 2019). The program aims at providing compact apartments (40-100 $\mathrm{m}^{2}$, depending on family size) with capped down-payments when signing the contract, ranging from 2,400 to 6,000 EUR (2019). Down-payments can be further reduced with means-tested loans provided by the City, and the allocation of SMART apartments is more strictly regulated (for details on down-payments and allocation criteria, see Chapter 4 by Litschauer and Friesenecker in this volume). From 2012 onwards, the tendering process required that one-third of all new subsidised housing units be built as SMART units, and this was extended to one half in 2019 (Wohnfonds Wien, 2019). In addition, projects experimented tentatively with the provision of other housing forms, such as subsidised dormitories, for example, in the form of night shelters for the homeless, or starter apartments as part of the Housing First approach (Reven-Holzmann, 2019).

Hence, developer competitions were adapted to ensure more equitable outcomes, while continuing to promote diversity and high housing quality. Subsidising LPHAs as hybrid actors allowed the City to respond to environmental and socio-demographic challenges, adopt norms and values accordingly, and enhance diversity in social housing. It has also allowed them to secure more equitable outcomes in the long run through limited-profit housing with the cost-covering principle in rent-setting and the requirement to reinvest profits into housing continue after the funding period. The introduction of SMART apartments shows that the City actively intervenes and balances the tradeoff between equity and diversity. Although this trade-off between high quality, diversity and affordability exists in new (social) housing, the City of Vienna continues to acknowledge the central role of housing for social cohesion, even in the light of pronounced urban challenges.

\section{Innovation by enhancing participation opportunities}

Vienna has traditionally been characterised by a top-down governing style, but in recent decades the City has enabled more opportunities for participation at the neighbourhood level (see Chapter 3 by Ahn and Mocca in this volume). Similarly, the participation of residents 
in planning and designing the living environment in (social) housing construction has traditionally been quite limited. However, with the introduction of social sustainability in 2009, the city administration increasingly promoted new modes of participation in developer competitions that aim at fostering collaborative housing.

Initially, the provision of communal rooms and green spaces did not result in higher usage rates, which is why issues of appropriation and self-management through residents became more central in developer competitions (Reven-Holzmann, 2019). The main response to this challenge was the introduction of so-called settlement management processes, which focus on tenants' participation after they move in. Equipped with a dedicated budget, consultants became part of interdisciplinary project teams to facilitate and mediate community building and self-organisation. Since that time, it has become standard not to fully equip and plan every community room in detail, but to leave it to tenants to clarify use concepts during the settlement process and to self-organise (parts of) the maintenance of community infrastructure. This should at least serve 'the committed residents' who are willing to co-design the use of community rooms according to their needs (Reven-Holzmann, 2019, p. 86). Vienna's approach to social housing construction, therefore, not only aims to address diversity by recognising diverse housing needs, but also enhances aspects of democracy by giving tenants the opportunity to participate (ibid.). Yet, participation is limited, as projects that allow for co-planning the apartment (layout) are rarely implemented. In general, social housing construction is still mainly characterised by top-down planning decisions to serve different needs in the long run.

With regard to fostering participation, but also in relation to serving diverse housing needs, Vienna's social housing approach also started to subsidise co-housing projects (Bau-und Wohngruppen) more prominently since 2009 . These projects are characterised by a selfdetermined approach of associations of citizens that initiate, plan and (co-)develop collaborative housing for self-use and communitarian services. Following a commissioned study, which explored the regulatory context and legal obstacles for co-housing in Vienna, procedures to allocate land to co-housing projects in urban development areas were introduced (Temel et al., 2009, p. 51). In 2012, wohnfonds_wien introduced specific co-housing competitions where land was allocated to co-housing projects. The City subsidised co-housing in order to establish diversity at the neighbourhood level, provide common spaces open to other residents of the neighbourhood and to foster vibrant neighbourhoods (Reven-Holzmann, 2019). 
Nevertheless, tenants in co-housing are usually more homogenous in socio-economic and socio-demographic terms than tenants in mainstream social housing. Following Temel et al. (2009), it is largely the higher educated groups with sufficient financial and time resources who are able to participate in and finance the planning process of such projects. Compared to the standard model of subsidised social housing built by limited-profit housing association, the provision of subsidised co-housing is very limited in scope (Gruber and Lang, 2018). Hence, their effect on the trade-off between equity and democracy is limited, but mostly better-off individuals benefit from this new mode of (social) housing construction. Nonetheless, these projects shape living conditions in the neighbourhood and influence prevailing social norms and existing relations between residents.

\section{Conclusions}

Given the vast but variegated transformations of social housing across Europe since the 1980s, this chapter aimed to fill the floating signifier on how the social is articulated in Vienna's social housing construction. Contrary to recent trends that restrict social housing to residents with limited financial resources (Granath Hansson and Lund, 2019), this chapter emphasises how Vienna's approach to social housing construction goes beyond simply producing affordable housing for low-income households. Rooted in the social-democratic history of the City of Vienna, social housing construction continues to pursue its core values: avoiding segregation and emphasising the social aspects of housing for the many. New social housing provides affordable, high-quality housing to a broad section of society, whilst also shaping the way people live together.

Unlike many other cities and countries that retrenched from state support for social housing, Vienna continued to actively influence prevailing norms, values and outcomes in social housing construction. With the interplay of land market intervention, housing construction subsidies and the specific use of developer competitions, Vienna retained its capacity to shape the social in social housing through a steering role. This renewed approach, which can be characterised as 'state-directed hybridity' (Mullins et al., 2017), depends on a specific actor's constellation in which LPHAs play a key role. Regulated at the national level, LPHAs share the City's values regarding social housing and, as actors of the third sector, are able to provide high-quality and affordable housing through cost-covering rent and the obligation to reinvest profits. 
A core instrument in addressing urban challenges and adapting social housing construction accordingly is the specific use of developer competitions. As projects must fulfil the requirements of affordable housing through rent caps, developer competitions demand innovative, high-quality housing solutions to address urban challenges. Whilst social housing construction specifically responded to ecological challenges during the 1990s, it increasingly addressed diverse housing needs and focused on solutions for socio-demographic changes. This was further mainstreamed by introducing social sustainability as a new criterion in developer competitions in 2009 , thereby enhancing diversity and democracy by influencing housing outcomes as well as residents' relations. Faced with affordability challenges, the City introduced SMART apartments to enhance equity. Moreover, by fostering different modes of participation, the City increasingly emphasised aspects of social cohesion within its social housing approach. This implies shifts in prevailing values and indicates redefinitions of the social in social housing.

Finally, through the lens of the just city (Fainstein, 2010), we assessed the outcomes of these redefinitions with regard to trade-offs between equity, diversity and democracy. Such trade-offs always exist in (social) housing and are also detectable in Vienna's approach. Since newly constructed housing is more expensive than the existing (social) housing stock, achieving equitable outcomes remains a challenge. However, by targeting the existing municipal housing stock at relatively disadvantaged groups (see Chapter 4 by Litschauer and Friesenecker), the City is able to buffer the trade-off with regard to equity in newly constructed social housing. By relying on limited profit housing, Vienna is additionally able to shape future housing in terms of enhancing the recognition of diverse housing needs and the limited incorporation of more participatory practices.

Social housing in Vienna has always been about more than providing affordable housing, also encompassing the aim of social cohesion. As the analysis of social innovation of developer competitions shows, this continues to the present day. In the European context, Vienna leads the way in developing new solutions in urban housing systems. Social housing is - and should be - about more than just affordable housing, since housing is not only an economic question but a social one, and justice refers to more than only economic redistribution.

\section{References}

Andersson, R., and Turner, M. L., 2014. Segregation, gentrification, and residualisation: from public housing to market-driven housing allocation in inner city Stockholm. International Journal of Housing Policy, 14(1), pp. 3-29. 
Bauer, E., 2006. Gemeinnütziger Wohnbau in Österreich. Zu Geschichte, Funktion und künftiger Perspektive. Kurswechsel, 3, pp. 20-27.

BEPA (Bureau of European Policy Advisors), 2011. Empowering people, driving change: Social innovation in the European Union.

Braga, M. and Palvarini, P., 2013. Social housing in the EU. Policy Department A: Economic and Scientific Policy, European Parliament (Brussels).

Fainstein, S., 2010. The just city. Ithaca, NY: Cornell University Press.

GBV, 2021. Leitbild der Gemeinnützigen. Available at: https://bit.ly/3u7dv3e [Accessed 28 March 2021].

Granath Hansson, A. and Lundgren, B., 2019. Defining social housing: A discussion on the suitable criteria. Housing, Theory and Society, 36(2), pp. 149-166. https://bit.ly/2YAUqg4

Gruber, E. and Lang, R., 2018. Collaborative housing models in Vienna through the lens of social innovation. In: Van Bortel, G., Gruis, V., Nieuwenhuijzen, J. and Pluijmers, B., eds., 2018. Affordable housing governance and finance innovations, partnerships and comparative perspectives. Abingdon and New York: Routledge, pp. 42-58.

Kadi, J. and Suitner, J., 2019. Red Vienna, 1919-1934. In: Orum, A.M., ed., 2019. The Wiley Blackwell encyclopedia of urban and regional studies, pp. 1-5. https://bit.ly/3fxr600

Lévy-Vroelant, C. and Reinprecht, C., 2014. Housing the poor in Paris and Vienna: The changing understanding of 'the social'. In: Scanlon, K., Whitehead, C. and Fernandez Arrigoitia, M., eds., 2014. Social housing in Europe. Oxford: Wiley-Blackwell, pp. 297-314.

Lévy-Vroelant, C., Reinprecht, C., Robertson, D. and Wassenberg, F., 2014. Learning from history: Path dependency and change in the social housing sectors of Austria, France, the Netherlands and Scotland, 1889-2013. In: Scanlon, K. and Fernandez Arrigoitia, M., eds., 2014. Social housing in Europe. Oxford: Wiley-Blackwell, pp. 277-296.

Liske, H., 2008. Der "Bauträgerwettbewerb” als Instrument des geförderten sozialen Wohnbaus in Wien - verfahrenstechnische und inhaltliche Evaluierung. [pdf] Available at: https://bit.ly/2PHcyjn [Accessed 01 April 2021]

MA18, 2005. Stadtentwicklungsplan 2005. Short Report. [pdf] Available at: https://bit.ly/3fxqlnC [Accessed 01 April 2021].

Marquardt, S. and Glaser, D., 2020. How much state and how much market? Comparing social housing in Berlin and Vienna. German Politics, aheadof-print, pp. 1-20.

Matznetter, W., 2002. Social housing policy in a conservative welfare state: Austria as an example. Urban Studies, 39(2), pp. 265-282.

Moulaert, F., 2010. Social innovation and community development. Concepts, theories and challenges. In: Moulaert, F., Swyngedouw, E., Martinelli, F. and Gonzalez, S., eds., 2010. Can neighbourhoods save the city? Community development and social innovation. London: Routledge, pp. 20-32.

Mullins, D., Milligan, V. and Nieboer, N., 2017. State directed hybridity? The relationship between non-profit housing organisations and the state in three national contexts. Housing Studies, 33(4), pp. 565-588. 


\section{Michael Friesenecker and Katharina Litschauer}

Mundt, A., Komendantova, N. and Amann, W., 2018. Berichtsstandard Wohnbauförderung 2018. [online] Available at: https://bit.ly/3rHMDp9 [Accessed 01 April 2021].

Reinprecht, C., 2021. The local dimension of housing policies. In: Kazepov, Y., Barberis, Mocca, E. and Cucca, R., eds., 2021. Handbook on urban social policy. International perspectives on multilevel governance and local welfare. Cheltenham: Edward Elgar. Forthcoming.

Reven-Holzmann, A., 2019. 10 Jahre "Soziale Nachhaltigkeit". Bestandsaufnahme und Ausblick. [pdf] Available at: https://bit.ly/3do29RJ [Accessed 01 April 2021].

Scanlon, K., Fernández Arrigoitia, M. and Whitehead, C.M.E., 2015. Social housing in Europe. European Policy Analysis, 17, pp. 1-12.

Schluder, M., 2005. 10 Jahre Bauträgerwettbewerb. Veränderungen im Wohnbau. [online] Available at: https://bit.ly/3meAWF9 [Accessed 01 April 2021].

Temel, R., Lorbek, M., Ptaszyńska, A. and Wittinger, D., 2009. Baugemeinschaften in Wien: Endbericht 1- Potenzialabschätzung und Rahmenbedingungen. [online] Available at: https://bit.ly/3uffrXQ [Accessed 01 April 2021].

Wohnfonds Wien, 2019. SMART-wohnen. [pdf] Available at: https://bit. ly/3wdd61n [Accessed March 28 2021]. 